\title{
PENGGUNAAN CENDAWAN ENTOMOPATOGEN Beauveria bassiana (BALSAMO) VUILLEMIN DAN Lecanicillium lecanii (ZIMM) ZARE \& GAMS UNTUK MENGENDALIKAN Helopeltis antonii SIGN (HEMIPTERA: MIRIDAE)
}

\author{
The Use of Entomopathogenic Fungi Beauveria bassiana (Balsamo)Vuillemin and \\ Lecanicillium lecanii (Zimm) Zare \& Gams) for Controlling Helopeltis antonii Sign \\ (Hemiptera: Miridae)
}

\author{
Sri Hastuti Anggarawati ${ }^{1}$, Teguh Santoso ${ }^{2}$, dan Ruly Anwar ${ }^{2}$ \\ ${ }^{1}$ Departemen Silvikultur, Fakultas Kehutanan IPB \\ ${ }^{2}$ Staf pengajar Departemen Proteksi Tanaman, Fakultas Pertanian IPB
}

\begin{abstract}
Helopeltis sp. has been known as one of major pests on tea, cacao and cashew plantation. Recently, genus Helopeltis is also reported attack Acacia plantation in Sumatra and Kalimantan. For such extensive plantation, low cost biocontrol agents like entomopathogenic fungi are choosen because of the simplicity for mass production. The objective of this study was to measure the effectiveness of Beauveria bassiana and Lecanicillium lecanii against Helopeltis sp. Both fungi that were used in this study were obtained from IPB Insect Pathology Laboratory. The tested insect, Helopeltis sp. was collected from Gunung Mas tea plantation. The insects were reared in laboratory. Four level of conidial density, 109, $10^{8}, 10^{7}, 10^{6}$ conidial $\mathrm{mL}$ were applied to Helopeltis adult (B. bassiana) and $3^{\text {rd }}$ instar nymph (L. lecanii). Daily mortality was observed until seven days post treatment. The result showed that $\mathrm{L}$. lecanii at $10^{6}$ conidia/mL caused $96.25 \%$ mortality of $3^{\text {rd }}$ instar nymph of Helopeltis $s p$. with the $L C_{50}$ value at two days observation was $1.03 \times 10^{6}$ conidia/ mL, $L T_{50}$ was 1.198 days and $L T_{95}$ was 5.25 days. On the other hand, B. bassiana at $10^{6}$ conidial mL caused $81.25 \%$. mortality of adult Helopeltis sp. while $100 \%$ mortality could be attained by using $10^{8}$ conidial $\mathrm{mL}$. The $\mathrm{LC}_{50}$ of $\mathrm{B}$. bassiana was $3.2 \times 10^{4}$ conidial $\mathrm{mL}$, at four days observation and $L T_{50}$ was 4.214 days. The two fungi were thus judged effective against Helopeltis sp. in this bio assay.
\end{abstract}

Key words: Beauveria bassiana, conidia, density, Helopeltis sp., Lecanicillium lecanii, mortality.

\section{PENDAHULUAN}

Helopeltis sp. merupakan salah satu hama penting pada berbagai jenis tanaman tropis, khususnya teh, kakao, kina, jambu mete dan lada, tetapi digolongkan sebagai hama minor di tanaman kehutanan. Kerusakannya kadang-kadang ditemukan pada tanaman mahoni, ketapang, kayu manis, dan melia. Laporan terkini menyebutkan bahwa kerusakan berat oleh Helopeltis sp. ini terjadi pada Eucalyptus muda dan tegakan akasia di Indonesia (Wylie et al. 1998 dalam Speight dan Wylie 2001). Tingkat kerusakan pada tanaman teh dapat mencapai $50 \%$ dan pada suatu saat akan meningkat mencapai 100\% (Sukasman 1996). Serangan Helopeltis sp. pada pucuk akasia menyebabkan bercak nekrotik pada daun dan kematian tunas muda. Kematian tunas muda tersebut disebabkan oleh cairan saliva yang bersifat toksik atau oleh patogen dalam proses serangannya (Nair dan Sumardi 2000). Luas serangan yang ditimbulkan pada tanaman akasia muda di Kalimantan Timur, dapat mencapai $100 \%$ (Santoso T 2013, komunikasi pribadi), dengan intensitas serangan bervariasi namun dapat mencapai $50 \%$.
Penggunaan insektisida seperti deltametrin telah digunakan oleh beberapa perusahaan Hutan Tanaman Industri (HTI) untuk mengendalikan Helopeltis sp. di lapangan (Nair dan Sumardi 2000).

Penggunaan pestisida dalam mengendalikan hama dan penyakit tidak hanya mencemari lingkungan dan menimbulkan resistensi hama, tetapi juga relatif mahal apabila diterapkan pada skala besar. Oleh karena itu, perlu dilakukan upaya pengendalian yang lebih murah dan bersifat ramah lingkungan, yaitu dengan menggunakan agens hayati seperti bakteri, virus, fungi, protozoa, ricketsia, dan nematoda. Di antara agens hayati tersebut, cendawan entomopatogen mempunyai prospek penting karena selain efektif juga lebih murah dan sederhana cara perbanyakannya. Entomopatogen mempunyai peran penting yang dapat menyebabkan tingginya kematian populasi serangga dan aman bagi serangga non target (Subramaniam et al. 2009).

Beberapa jenis cendawan entomopatogen yang telah dimanfaatkan untuk mengendalikan hama antara lain Metarhizium anisopliae, Beauveria bassiana, dan Lecanicillium sp. (=Verticillium sp.). Entomopatogen $B$. bassiana dan $L$. lecanii merupakan cendawan yang 
sudah diketahui keefektifannya dalam mengendalikan sejumlah serangga hama.

Cendawan $B$. bassiana mampu mengendalikan 80 $100 \%$ hama tungau (Deciyanto dan Indrayani 2009), 100\% larva dan $73.75 \%$ imago Brontispa longissima (Hosang et al. 2004). Suspensi konidia B. bassiana dengan konsentrasi $1.1 \times 10^{8}$ konidia/ mL air yang diaplikasikan langsung pada serangga Helopeltis antonii di laboratorium, menyebabkan kematian serangga sebesar $94-98 \%$, sedangkan yang diaplikasikan pada pakan dapat menyebabkan kematian sebesar $86-92 \%$ (Suriati 2008).

Cendawan L. lecanii merupakan salah satu agen pengendali hayati yang potensial untuk digunakan pada hama-hama pertanian, seperti kutudaun, kutuputih, thrips, dan kutu kebul (Ferron 1985). Cendawan $L$. lecanii mampu mengendalikan Scirtothrips bispinosus (Subramaniam et al. 2010), Aphis gossypii (Gurulingappa et al. 2010), Riptortus linearis (Prayogo 2009). Khusus terhadap Helopeltis sp., Solikhah (2013) telah menunjukkan kemampuan cendawan L. lecanii dalam menghambat penetasan telur, namun penelitian terkait potensi cendawan tersebut untuk pengendalian nimfa dan imago Helopeltis sp. belum dilakukan.

Penelitian ini dilakukan untuk mengukur potensi cendawan $B$. bassiana dan $L$. lecanii dalam mengendalikan serangga hama Helopeltis sp.

\section{Tujuan Penelitian}

Mengetahui keefektifan cendawan entomopatogen $B$. bassiana dan $L$. lecanii terhadap serangga hama $H$. antonii

\section{BAHAN DAN METODE}

\section{Tempat dan Waktu}

Kegiatan penelitian dilakukan di Laboratorium Patologi Serangga Departemen Proteksi Tanaman Fakultas Pertanian IPB. Penelitian dilaksanakan mulai bulan Januari- Juli 2013.

\section{Serangga dan Cendawan Uji}

\section{Perbanyakan Serangga Uji}

Serangga uji yang digunakan dalam penelitian adalah serangga $H$. antonii yang diperoleh dari Perkebunan Teh Gunung Mas. Serangga yang diperoleh dari lapangan dipelihara dan diperbanyak sesuai metode perbanyakan $H$. antonii oleh Kilin dan Atmaja (1999) yaitu dengan menggunakan pakan buah ketimun. Buah ketimun dimasukkan ke dalam wadah plastik berdiameter $16 \mathrm{~cm}$ dan tinggi $17 \mathrm{~cm}$. Posisi ketimun berdiri dengan cara disandarkan pada dinding wadah bagian dalam. Sepasang imago dimasukkan ke dalam wadah tersebut dan ditutup dengan kain kasa. Ketimun diganti setiap hari dengan ketimun yang baru. Ketimun yang berisi telur, setelah dihitung jumlah telurnya dimasukkan ke dalam wadah lain dan ditutup dengan kain kasa. Nimfa instar 1 yang telah muncul dimasukkan ke dalam wadah baru yang berisi ketimun. Pakan tersebut diganti setiap hari sampai diperoleh jumlah dan stadia serangga yang digunakan.

\section{Cendawan Uji}

Cendawan $B$. bassiana dan $L$. lecanii yang digunakan dalam penelitian, merupakan koleksi Laboratorium Patologi Serangga Departemen Proteksi Tanaman Fakultas Pertanian IPB. B. bassiana berasal dari serangga Leptocorisa oratorius, sedangkan $L$. lecanii diisolasi dari Riptortus linearis. Untuk menguji tingkat virulensinya, kedua cendawan tersebut diinokulasikan pada imago Tenebrio molitor (Coleoptera: Tenebrionidae). Miselia yang keluar dari serangga tersebut diisolasi ke media PDA, kemudian dipindahkan ke media beras. Beras dicuci bersih kemudian dikukus setengah matang dengan api kecil selama \pm 15-20 menit. Beras dikeringanginkan untuk menghilangkan uap panas, kemudian dimasukkan ke dalam kantong plastik tahan panas sebanyak $50 \mathrm{~g}$ dan disterilisasi dengan autoklaf pada suhu $121^{\circ} \mathrm{C}$ dan tekanan 2 atm selama 15 menit. Proses pemindahan inokulum cendawan ke media beras dilakukan di Laminar Air Flow dengan memasukkan potongan media PDA yang ditumbuhi cendawan ke dalam media beras, kemudian plastik ditutup rapat. Media beras disimpan di dalam ruangan yang gelap pada suhu kamar selama 21 hari.

\section{Penyiapan Suspensi Cendawan Entomopatogen}

Biakan B. bassiana dan L. lecanii pada media beras yang telah berumur 21 hari disiapkan sebanyak $100 \mathrm{~g}$ (2 kantong plastik). Media beras tersebut digerus dengan menggunakan mortar sampai halus. Biakan cendawan yang sudah dihaluskan ditambahkan $100 \mathrm{~mL}$ air disterilkan yang telah dicampur dengan Tween 20 (konsentrasi $0.05 \%$ ). Penyaringan dilakukan untuk memisahkan media beras dengan suspensi konidia. Suspensi konidia yang telah disaring kemudian dikocok dengan menggunakan vortex selama 30 detik. Suspensi yang telah dikocok kemudian dihitung jumlah konidianya dengan menggunakan haemocytometer Neubauer-improved. Selanjutnya dilakukan pengenceran dengan air steril hingga diperoleh kerapatan konidia $10 \%$ mL. Demikian seterusnya dibuat pengenceran bertingkat untuk mendapatkan kerapatan konidia $10^{8} / \mathrm{mL}, 10^{7} / \mathrm{mL}$, dan $10^{6} / \mathrm{mL}$, yang dibutuhkan untuk perlakuan.

\section{Aplikasi cendawan B. bassiana dan L. lecanii}

Empat perlakuan kerapatan konidia $10^{6}, 10^{7}, 10^{8}$, dan $10^{9}$ konidia/mL dari suspensi B. bassiana dan kontrol, disemprotkan pada imago $H$. antonii. Dengan perlakuan kerapatan konidia yang sama, $10^{6}, 10^{7}, 10^{8}$, dan $10^{9}$ konidia/mL dari suspensi L. lecanii dan kontrol, disemprotkan pada nimfa instar ke-3 $H$. antonii yang ditempatkan pada wadah plastik. Perlakuan diulang sebanyak empat kali dengan jumlah serangga 20 ekor/ ulangan. Aplikasi penyemprotan menggunakan sprayer tangan dengan volume semprot $\pm 2 \mathrm{~mL}$ suspensi per ulangan, sedangkan untuk kontrol serangga disemprot dengan air steril yang dicampur Tween 20. Serangga uji 
yang telah disemprot dimasukkan ke dalam wadah plastik yang telah diberi pakan pucuk akasia. Pucuk tersebut diganti setiap hari untuk menjaga kesegaran pakan $H$. antonii. Pengamatan dilakukan setiap hari sampai hari ke-7 setelah aplikasi. Pengamatan dilakukan terhadap mortalitas, waktu terjadinya mortalitas, dan perkembangan pertumbuhan cendawan patogen.

\section{Analisis Data}

Perbedaan mortalitas antar tingkat kerapatan konidia dan kontrol dianalisis dengan program SPSS 13.0 for windows dan diuji dengan uji duncan $(\alpha=0.05)$. Konsentrasi kematian $\left(\mathrm{LC}_{50}\right)$ dan waktu kematian $\left(\mathrm{LT}_{50}\right)$ dihitung dengan analisis probit menggunakan program Polo Plus Probit and Logit Analysis 1.0 LeOra Software.

\section{HASIL DAN PEMBAHASAN}

Persentase mortalitas nimfa $H$. antonii yang terinfeksi oleh $L$. lecanii tercantum pada Tabel 1. Cendawan L. lecanii mampu mematikan $H$. antonii lebih dari $50 \%$ pada pengamatan hari pertama untuk kerapatan $10^{7}, 10^{8}$, dan $10^{9}$ konidia/mL. Pada hari ke-3 setelah perlakuan terlihat bahwa kerapatan $10^{9} / \mathrm{mL}, L$. lecanii mampu mematikan $100 \% H$. antonii (Tabel 1). Pada kerapatan konidia $10^{8}, 10^{7}, 10^{6} / \mathrm{mL}$ sampai pada akhir pengamatan (hari ke-7), mortalitas serangga $H$. antonii mencapai lebih dari $95 \%$ tetapi tidak sampai $100 \%$. Hal ini menunjukkan bahwa dalam percobaan ini aplikasi $L$. lecanii efektif mematikan $H$. antonii.

Hasil uji statistika menunjukkan bahwa pada perlakuan kontrol tidak ada penambahan mortalitas $H$. antonii pada setiap hari pengamatan, berbeda nyata dengan perlakuan kerapatan konidia $10^{6}, 10^{7}, 10^{8}$, dan $10^{9} / \mathrm{mL}$. Pada kerapatan konidia $10^{9} / \mathrm{mL}$, mortalitas $H$. antonii terus meningkat setiap harinya sampai pada hari ke-3 setelah perlakuan, dengan mortalitas mencapai $100 \%$. Demikian juga kerapatan konidia $10^{8}$ dan $10^{7}$ $/ \mathrm{mL}$ mengakibatkan mortalitas $H$. antonii yang terus meningkat setiap harinya sampai pada hari ke-4 HSP sebesar $98.75 \%$ dan $97.5 \%$. Sementara pada kerapatan $10^{6} / \mathrm{mL}$. mortalitas $H$. antonii terus meningkat sampai hari ke-6 HSP sebesar 96.25\%. Mortalitas ini meningkat seiring meningkatnya kerapatan konidia yaitu $97.5 \%$ untuk kerapatan konidia $10^{7} / \mathrm{mL}$, sebanyak $98.75 \%$ untuk kerapatan konidia $10^{8} / \mathrm{mL}$, dan $100 \%$ untuk kerapatan konidia $10^{9} / \mathrm{mL}$.

Hubungan antara mortalitas $H$. antonii dengan kerapatan konidia ditunjukkan dengan persamaan regresi $y=8 x+66.25$. Artinya, jika kerapatan konidia L. lecanii naik sebesar satu unit satuan, maka mortalitas akan ikut naik sebesar 8\% (Gambar 1). Dengan menggunakan empat kerapatan konidia $10^{6}, 10^{7}, 10^{8}$, $10^{9}$ konidia $/ \mathrm{mL}$, garis regresi yang diperoleh menunjukkan hubungan linear dengan nilai $\mathrm{R}^{2}=0.914$. Karena tidak ada mortalitas serangga kontrol, data percobaan ini dianggap tidak menunjukkan heterogenitas data yang tinggi.

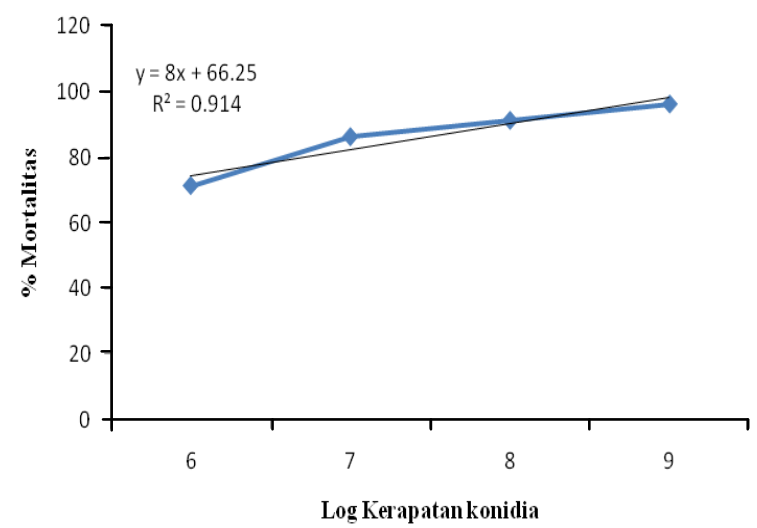

Gambar 1 Hubungan antara kerapatan konidia dengan mortalitas $H$. antonii yang terinfeksi cendawan $L$. lecanii pada hari kedua pengamatan.

L. lecanii mampu menginfeksi nimfa $H$. antonii mencapai $100 \%$ untuk kerapatan konidia $10 \% / \mathrm{mL}$ dan pada kerapatan konidia terendah yaitu $10^{6} / \mathrm{mL}$ juga mampu mematikan lebih dari $90 \%$ serangga uji. Serangga uji yang telah mati memperlihatkan adanya miselia yang keluar pada ruas-ruas tungkainya. Pada hari ke-3 setelah kematian, miselia $L$. lecanii mulai tumbuh dan semakin lama semakin menutupi bagian tubuh serangga uji. Setelah dilakukan pengamatan konidia dibawah mikroskop, terlihat bahwa cendawan tersebut mempunyai deskripsi yang sesuai dengan $L$. lecanii yang diaplikasikan (Gambar 3a), yaitu konidia yang berbentuk lonjong, seragam, terlihat memisah, berpasangan atau melingkar sepanjang hifa atau berkumpul pada ujung hifa, dan konidia terbungkus di dalam kantong lendir (Humber 1997).

Tingginya tingkat mortalitas nimfa oleh $L$. lecanii bisa disebabkan karena integumen nimfa yang lunak dan tipis sehingga $L$. lecanii lebih mudah menginfeksi serangga uji. Infeksi $L$. lecanii pada tubuh nimfa $H$. antonii, mampu mempengaruhi serangga uji ini dalam melakukan proses ganti kulit, hal ini terlihat dari adanya serangga uji yang mengalami kegagalan dalam proses ganti kulit.

Pada hari ke-4 setelah aplikasi B. bassiana, serangga $H$. antonii berhasil terinfeksi lebih dari $90 \%$ untuk kerapatan konidia $10^{8}$ dan $10^{9} / \mathrm{mL}$. Pada kerapatan konidia $10^{7}$ dan $10^{6} / \mathrm{mL}$, mortalitas serangga $H$. antonii mencapai lebih dari $50 \%$ pada hari yang sama. Pada pengujian serangga $H$. antonii dengan menggunakan $B$. bassiana, digunakan serangga imago dengan jumlah jantan dan betina seimbang. Pada pengamatan hari ketujuh, mortalitas serangga sebesar $81.25 \%$ terjadi pada kerapatan konidia $10^{6} / \mathrm{mL}$, sedangkan pada kerapatan konidia $10^{7} / \mathrm{mL}$ mortalitas serangga mencapai 97.50\%. Pada kerapatan konidia $10^{8}$ dan $10^{9} / \mathrm{mL}$, mortalitas $H$. antonii sebesar $100 \%$ (Tabel 2). Hal ini menunjukkan bahwa dalam percobaan ini aplikasi $B$. bassiana efektif mematikan serangga $H$. antonii.

Uji statistika menunjukkan bahwa pada perlakuan kontrol tidak ada penambahan mortalitas $H$. antonii pada setiap hari pengamatan, berbeda nyata dengan perlakuan kerapatan konidia $10^{6}, 10^{7}, 10^{8}$, dan $10^{9} / \mathrm{mL}$ pada hari ke-2 HSP. Pada konsentrasi kerapatan $10^{9}$ dan 
$10^{8}$ konidia/ mL, mortalitas $H$. antonii terus meningkat setiap harinya sampai pada hari ke-5 HSP, dengan mortalitas mencapai $100 \%$. Demikian juga pada kerapatan konidia $10^{7} / \mathrm{mL}$ mortalitas $H$. antonii terus meningkat setiap harinya sampai pada hari ke-7 HSP sebesar $97.50 \%$. Sementara pada kerapatan konidia $10^{6}$ $/ \mathrm{mL}$, mortalitas $H$. antonii terus meningkat sampai hari ke-7 HSP sebesar $81.25 \%$.

Hubungan antara mortalitas $H$. antonii dengan kerapatan konidia ditunjukkan dengan persamaan regresi $\mathrm{y}=16.5 \mathrm{x}+39.37$. Artinya, jika kerapatan konidia $B$. bassiana naik sebesar satu unit satuan, maka mortalitas akan ikut naik sebesar $16.5 \%$ (Gambar 2). Dengan menggunakan empat kerapatan konidia $10^{6}$, $10^{7}, 10^{8}, 10^{9}$ konidia/mL, garis regresi yang diperoleh menunjukkan hubungan linear dengan nilai $\mathrm{R}^{2}=0.902$. Karena tidak ada mortalitas serangga kontrol, data percobaan ini dianggap tidak menunjukkan heterogenitas data yang tinggi.

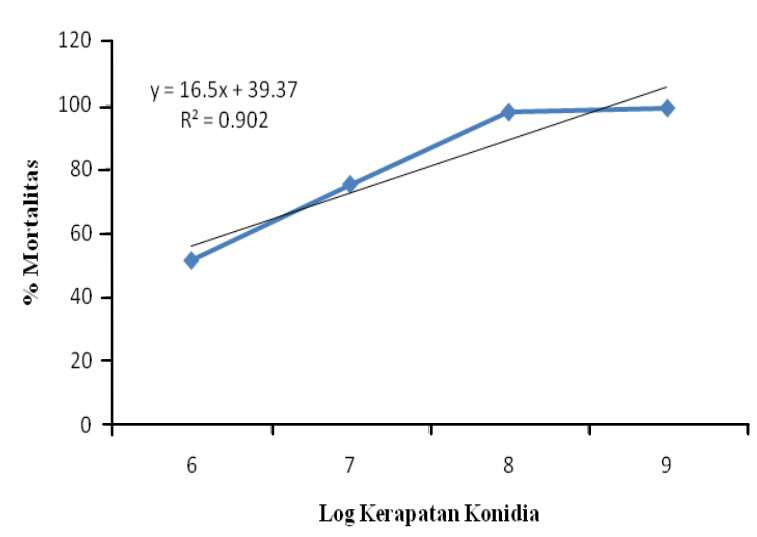

Gambar 2 Hubungan antara kerapatan konidia dengan mortalitas $H$. antonii yang terinfeksi cendawan B. bassiana pada hari keempat pengamatan.

Tabel 1 Persentase mortalitas kumulatif harian nimfa H. antonii yang terinfeksi cendawan L. Lecanii pada berbagai kerapatan konidia

\begin{tabular}{|c|c|c|c|c|c|c|c|}
\hline \multirow{3}{*}{ Perlakuan konidia/ mL } & \multicolumn{7}{|c|}{ Mortalitas (\%) } \\
\hline & \multicolumn{7}{|c|}{ Hari Setelah Perlakuan (HSP) } \\
\hline & 1 & 2 & 3 & 4 & 5 & 6 & 7 \\
\hline Kontrol & 0 & 0 & 0 & 0 & 0 & 0 & 0 \\
\hline $10^{9}$ & 78.75 & 96.25 & 100.00 & 100.00 & 100.00 & 100.00 & 100.00 \\
\hline $10^{8}$ & 77.50 & 91.25 & 96.25 & 98.75 & 98.75 & 98.75 & 98.75 \\
\hline $10^{7}$ & 65.00 & 86.25 & 96.25 & 97.50 & 97.50 & 97.50 & 97.50 \\
\hline $10^{6}$ & 42.50 & 71.25 & 83.75 & 91.25 & 95.00 & 96.25 & 96.25 \\
\hline
\end{tabular}

Tabel 2. Persentase mortalitas kumulatif imago H. antonii yang terinfeksi cendawan B. bassiana.

\begin{tabular}{|c|c|c|c|c|c|c|c|}
\hline \multirow{3}{*}{ Perlakuan konidia/ mL } & \multicolumn{7}{|c|}{$\%$ Mortalitas $(\%)$} \\
\hline & \multicolumn{7}{|c|}{ Hari Setelah Perlakuan (HSP) } \\
\hline & 1 & 2 & 3 & 4 & 5 & 6 & 7 \\
\hline kontrol & 0 & 0 & 0 & 0 & 0 & 0 & 0 \\
\hline $10^{9}$ & 07.50 & 16.25 & 41.25 & 98.75 & 100.00 & 100.00 & 100.00 \\
\hline $10^{8}$ & 03.75 & 16.25 & 45.00 & 97.50 & 100.00 & 100.00 & 100.00 \\
\hline $10^{7}$ & 03.75 & 08.75 & 21.25 & 75.00 & 87.50 & 87.50 & 97.50 \\
\hline $10^{6}$ & 03.75 & 13.75 & 20.00 & 51.25 & 65.00 & 68.75 & 81.25 \\
\hline
\end{tabular}

Berdasarkan hasil analisis probit cendawan $L$. lecanii yang dilakukan pada hari kedua HSP, diperoleh $\mathrm{LC}_{50}$ sebesar $1.03 \times 10^{6} \mathrm{konidia} / \mathrm{mL}$, sedangkan untuk nilai $\mathrm{LT}_{50}$ dan $\mathrm{LT}_{95}$ masing-masing adalah 1.198 (1 - 2 hari) dan 5.25 ( $5-6$ hari). Dengan kata lain, kerapatan konidia yang dibutuhkan untuk mengendalikan $50 \%$ populasi adalah $1.03 \times 10^{6} \mathrm{konidia} / \mathrm{mL}$, dan dengan kerapatan ini, $50 \%$ populasi serangga $H$. antonii dikendalikan dalam waktu 1.2 hari. Sebagai perbandingan, dengan menggunakan isolat cendawan yang sama, Agustin (2013) mendapatkan nilai LC $_{50}$ untuk hama penggerek batang jagung Ostrinia furnacalis sebesar $1.62 \times 10^{6}$ konidia $/ \mathrm{mL}$. Solikhah (2013) memperoleh nilai $\mathrm{LC}_{50}$ L. lecanii untuk telur $H$. antonii sebesar $3.3 \times 10^{7} \mathrm{konidia} / \mathrm{mL}$. Hasil ini juga mengindikasikan bahwa serangga hama $H$. antonii sangat rentan terhadap infeksi oleh L. lecanii. Hal ini menunjukkan bahwa apabila dibandingkan dengan telur, nimfa instar ketiga $H$. antonii yang diteliti cenderung lebih rentan terhadap L. lecanii. Kerentanan yang tinggi ini karena serangga uji yang digunakan adalah nimfa instar ke-3 dan diduga pada stadia ini integument serangga masih mudah ditembus oleh cendawan.

Hasil analisis probit cendawan $B$. bassiana yang dilakukan pada hari keempat HSP, diperoleh $\mathrm{LC}_{50}$ sebesar $3.2 \times 10^{4}$ konidia $/ \mathrm{mL}$, sedangkan untuk $\mathrm{LT}_{50}$ dan $\mathrm{LT}_{95}$ masing-masing adalah 4.214 (4 - 5 hari) dan 13.050 (13 hari). Dengan kata lain, kerapatan konidia yang dibutuhkan untuk mengendalikan $50 \%$ populasi adalah $3.2 \times 10^{4}$ konidia/ mL, dan dengan kerapatan ini, $50 \%$ populasi serangga $H$. antonii dikendalikan dalam waktu 4.2 hari (Tabel 3). Zulyusri (2005) memperoleh nilai $\mathrm{LC}_{50}$ cendawan $B$. bassiana terhadap larva Crocidolomia pavonana (Lepidopera: Pyralidae) sebesar 2.01 X $10^{9}$ konidia/mL. Ratissa (2011) memperoleh nilai $\mathrm{LC}_{50}$ B. bassiana untuk Cylas formicarius sebesar 1.1 x $10^{9}$ konidia/mL. Jika dibandingkan nilai $\mathrm{LC}_{50}$ antar beberapa serangga 
tersebut, terlihat bahwa $H$. antonii sangat rentan terhadap infeksi oleh $B$. bassiana.

Tabel 3 Nilai $\mathrm{LC}_{50}, \mathrm{LT}_{50}$, dan $\mathrm{LT}_{95}$ cendawan $B$. bassiana dan L. lecanii terhadap H. antonii.

\begin{tabular}{lll}
\hline Analisis probit & B. bassiana & L. lecanii \\
\hline $\mathrm{LC}_{50}$ & $3.2 \times 10^{4}$ & $1.03 \times 10^{6}$ \\
& konidia/mL & konidia/mL \\
$\mathrm{LT}_{50}$ & 4.214 hari & 1.198 hari \\
$\mathrm{LT}_{95}$ & 13.050 hari & 5.25 hari \\
\hline
\end{tabular}

Konidia cendawan $B$. bassiana mulai berkecambah pada hari ke-2 setelah perlakuan. Hal tersebut dapat diketahui dari adanya miselia yang tumbuh pada ruasruas tungkai dan antena serangga inang juga pada bagian thoraks serangga inang. Miselia tersebut kemudian tumbuh dan berkembang, sehingga seluruh tubuh serangga inang dipenuhi oleh miselia cendawan $B$. bassiana. Setelah dilakukan pengamatan konidia dibawah mikroskop, terlihat bahwa cendawan tersebut mempunyai deskripsi yang sesuai dengan $B$. bassiana yang diaplikasikan (Gambar 3b), yaitu memiliki ciri

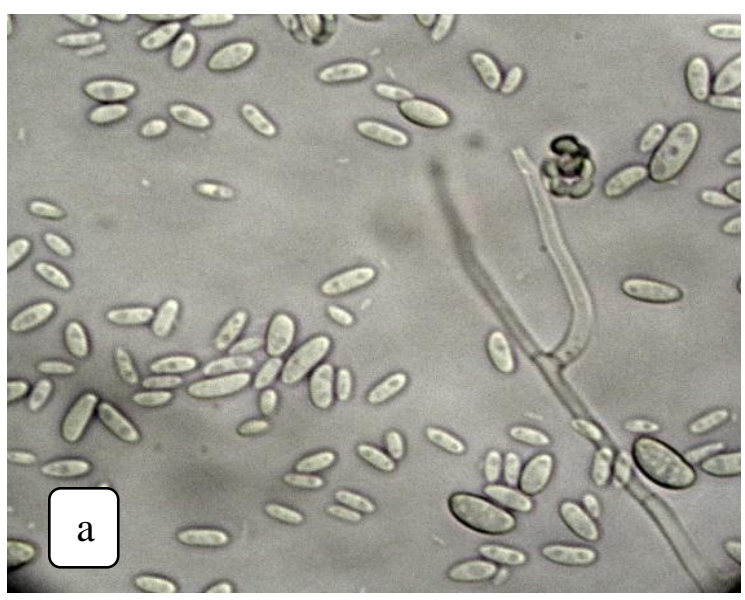

Gambar 3 Konidia cendawan L. lecanii (a) dan B. bassiana (b) (pembesaran 400x).

Mortalitas imago $H$. antonii oleh $B$. bassiana sangat tinggi, yaitu sebesar $100 \%$ pada kerapatan konidia $10^{9}$ /mL. Pada kerapatan $10^{8}$ konidia/mL, kematian yang diakibatkan mencapai $97.5 \%$. Hasil ini sesuai dengan yang diperoleh Suriati (2008) yang menyatakan bahwa suspensi konidia $B$. bassiana dengan konsentrasi $1.1 \mathrm{x}$ $10^{8} \mathrm{konidia} / \mathrm{mL}$ air yang diaplikasikan langsung pada serangga $H$. antonii di laboratorium, menyebabkan kematian serangga sebesar $94-98 \%$, sedangkan yang diaplikasikan pada pakan pengganti (buah mentimun) menyebabkan kematian sebesar $86-92 \%$.

Cendawan entomopatogen $B$. bassiana dan $L$. lecanii merupakan salah satu alternatif pengendalian hayati yang murah dan mudah. Apabila diaplikasikan di areal yang sangat luas seperti HTI, kedua cendawan ini sangat mudah untuk diproduksi karena pada umumnya aplikasi pengendalian hayati di lapangan dengan memanfaatkan cendawan yang dibiakkan pada media beras. Berdasarkan perhitungan sederhana, diketahui bahwa dengan menggunakan $400 l$ volume semprot untuk areal seluas 1 ha, hanya memerlukan sekitar $40 \mathrm{~kg}$ beras. Hal ini menunjukkan bahwa pemanfaatan kedua konidia yang berbentuk bulat dengan percabangan konidiofor yang berbentuk zig-zag, konidiofor biasanya bergerombol atau melingkar atau sendiri-sendiri, tidak berwarna, serangga yang terinfeksi akan terlihat adanya miselia cendawan berwarna putih, yang menutupi seluruh tubuhnya (Humber 1997). Menurut Ferron (1985) cendawan entomopatogen akan melewati dua siklus yaitu siklus parasit dan siklus saprofit. Siklus parasit dimulai dari penempelan konidia ke tubuh serangga (dalam hal ini aplikasi penyemprotan) sampai dengan serangga mati. Kematian serangga inang diakibatkan oleh kolonisasi cendawan didalam tubuh inang disertai dengan toksikasi oleh racun yang diproduksi oleh cendawan. Cendawan $B$. bassiana mengeluarkan toksin beauvericin. Dalam percobaan ini, kematian serangga dapat berlangsung dalam 1 hari sesudah perlakuan. Siklus saprofit dimulai sejak kematian serangga sampai kemunculan cendawan di permukaan tubuh inang. Dalam percobaan ini, siklus saprofit dapat teramati mulai hari kedua.

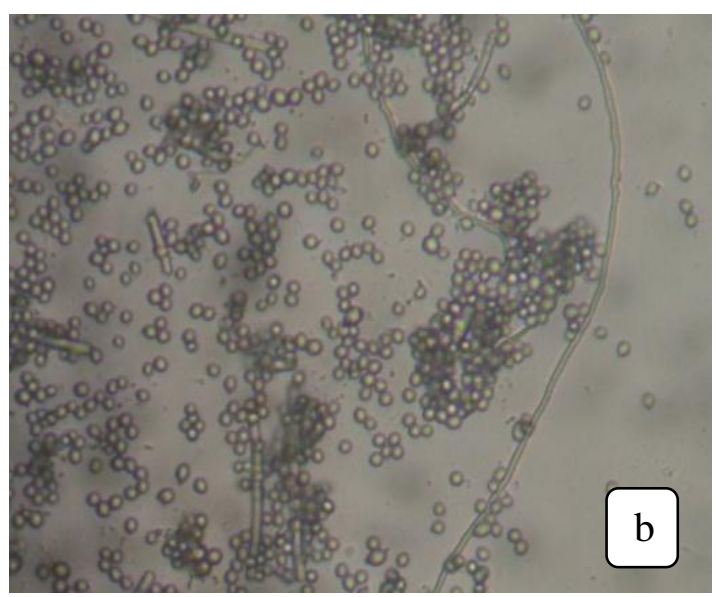

jenis cendawan ini cukup murah, efektif dan efisien untuk pengendalian di lapangan.

\section{SIMPULAN DAN SARAN}

Cendawan entomopatogen $L$. lecanii menyebabkan mortalitas nimfa instar ketiga $H$. antonii sebesar $100 \%$ pada kerapatan konidia $10^{9} / \mathrm{mL}$. Nilai $\mathrm{LC}_{50}$ sebesar 1.03 x $10^{6}$ konidia/ $\mathrm{mL}, \mathrm{LT}_{50}$ dan $\mathrm{LT}_{95}$ masing-masing adalah 1.198 ( 1 - 2 hari) dan 5.25 ( 5 - 6 hari).

Cendawan entomopatogen $B$. bassiana berhasil menyebabkan mortalitas imago $H$. antonii sebesar $100 \%$ pada kerapatan konidia $10^{8}$ dan $10^{9} / \mathrm{mL}$ di laboratorium. Nilai $\mathrm{LC}_{50}$ sebesar $3.2 \times 10^{4}$ konidia/ $\mathrm{mL}, \mathrm{LT}_{50}$ dan $\mathrm{LT}_{95}$ masing-masing adalah 4.214 (4 - 5 hari) dan 13.050 (13 hari).

Hal ini menunjukkan bahwa dalam percobaan ini aplikasi $B$. bassiana dan $L$. lecanii efektif mematikan serangga $H$. antonii. 


\section{DAFTAR PUSTAKA}

Agustin D. 2013. Uji keefektifan cendawan entomopatogen Beauveria bassiana (Balsamo) Vuillemin dan Lecanicillium lecanii (Zimm.) Zare \& Gams terhadap telur dan larva penggerek batang jagung asia Ostrinia furnacalis (Lepidoptera: Crambidae) [tesis]. Bogor (ID): Sekolah Pascasarjana Institut Pertanian Bogor.

Deciyanto S dan Indrayani IGAA. 2009. Jamur entomopatogen Beauveria bassiana: potensi dan prospeknya dalam pengendalian hama tungau. Perspektif (Ind). 8(2): 65-73.

Ferron P. 1985. Fungal control. Di dalam: Kerkut GA, Gilbert LI, editor. Comprehensive Insect Physiology Biochemistry and Pharmacology; Volume 12. Oxford (EG): Pergamon Press. hlm 313-346.

Gurulingappa P, Peter Allan McGee, Sword G. 2010. Endophytic Lecanicillium lecanii and Beauveria bassiana reduce the survival and fecundity of Aphis gossypii following contact with conidia and secondary metabolites. J CroPro. 30 (2011):

349-353. doi:10.1016/j.cropro.2010.11.017

Hosang MLA, Tumewan F, Alouw JC. 2004. Efektivitas cendawan entomopatogen Metarhizium anisopliae var. anisopliae dan Beauveria bassiana terhadap hama Brontispa longissima. Prosiding simposium IV hasil penelitian tanaman perkebunan: 2004 Sept 2830: Bogor. Bogor (ID): Pusat Penelitian dan Pengembangan Perkebunan. hlm 561-568.

Humber RA. 1997. Fungi: Identification. Di dalam: Lacey L, editor. Manual of Techniques in Insect Patology. California (US): Academic Press. hlm 153-185.

Kilin D dan Atmaja WR. 1999. Perbanyakan serangga Helopeltis antonii Sign. pada buah ketimun dan pucuk jambu mente. J Pen Tan Inds. 5(4): 119122.

Nair KSS dan Sumardi. 2000. Insect pests and diseases of major plantation species. Di dalam: Nair
KSS, editor. Insect Pests and Diseases in Indonesian Forests. Bogor (ID). Cifor. hlm 15.

Prayogo Y. 2009. Kajian cendawan entomopatogen Lecanicillium lecanii (Zimm.) (Viegas) Zare \& Gams untuk menekan perkembangan telur hama pengisap polong kedelai Riptortus linearis (F.) (Hemiptera: Alydidae) [disertasi]. Bogor (ID): Sekolah Pascasarjana, Institut Pertanian Bogor.

Ratissa DA. 2011. Keefektifan cendawan entomopatogen Beauveria bassiana (Bals.) Vuill terhadap Cylas formicarius (F.) (Coleoptera: Brentidae) dan pengaruhnya pada keperidian [skripsi]. Bogor (ID): Fakultas Pertanian Institut Pertanian Bogor.

Solikhah DR. 2013. Infektivitas cendawan Lecanicillium lecanii terhadap telur Helopeltis sp. (Hemiptera: Miridae) [skripsi]. Bogor (ID): Fakultas Pertanian Institut pertanian Bogor.

Speight MR dan Wylie FR. 2001. Insect Pests of Tropical Forestry. New York (US): CABI Publishing.

Subramaniam MSR, Babu A, Pradeepa N. 2010. A new report of entomopathogen, Lecanicillium lecanii infecting larvae of the tea thrips, Scirtothrips bispinosus (Bagnall). J Biosci. 1(3): 146-148.

Sukasman. 1996. Entomopatogen sebagai insektisida. Di dalam: Martosupono et al. Alternatif Pengendalian Hama Teh secara Hayati. Prosiding Seminar Sehari: 1996 Des 5: Gambung. Bandung (ID): Pusat Penelitian Teh dan Kina. hlm 31-40.

Suriati S. 2008. Beauveria bassiana dan Metarrhizium anisopliae bio insektisida ramah lingkungan. Warta Penelitian \& Pengembangan Tanaman Industri. 14(2): 30-31.

Zulyusri. 2005. Interaksi antara cendawan entomopatogen Beauveria bassiana (Bals.) Vuill. (Deuteromycotina: Hyphomycetes), parasitoid Eriborus argenteopilosus Cammeron (Hymenoptera: Ichneumonidae) dan hama kubis Crocidolomia pavonana (F.) (Lepidoptera: Pyralidae). 